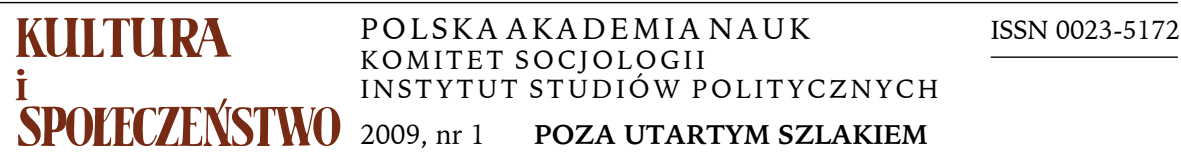

TOMASZ ZARYCKI

Uniwersytet Warszawski

\title{
SOCJOLOGIA KRYTYCZNA NA PERYFERIACH
}

\section{KAPITAŁ KULTUROWY JAKO KLUCZOWY WYMIAR NIERÓWNOŚCI}

Klasyczna zachodnia socjologia krytyczna koncentruje się, jak wiadomo, na problemie nierówności ekonomicznych. Dla większości przedstawicieli tego kierunku są one de facto jedynymi realnymi nierównościami, w szczególności w społeczeństwach nowoczesnych. Inne wymiary nierówności zwykle są uznawane za wtórne czy pozorne. Typowym przykładem takiego podejścia jest teoria społeczna wybitnego francuskiego socjologa Pierre'a Bourdieu. Wiele uwagi poświęcił on roli kapitału kulturowego, który sam zdefiniował jako istotny wymiar nierówności i dominacji społecznej (Bourdieu 1986). Jednak także Bourdieu - idąc między innymi śladami Marksa - uznawał kapitał kulturowy, a więc ogół wiedzy i zinstytucjonalizowanego wykształcenia oraz „ucieleśnionych" predyspozycji: gustów i kompetencji w zakresie konsumpcji kultury wysokiej i jej konwencji, za wymiar wtórny nierówności. Najwyraźniej dostrzec to można $\mathrm{w}$ jego słynnej pracy na temat reprodukcji, czyli niejawnych mechanizmów ograniczających dostęp młodzieży z niższych warstw społecznych do elitarnego wykształcenia we współczesnej mu Francji. Bourdieu (2005) zwraca w niej uwagę na kluczową rolę kapitału kulturowego jako czynnika reprodukcji pozycji klasowej. Pokazuje, jak egzaminy na poszczególnych etapach systemu edukacyjnego służą legitymizacji prawa dzieci rodziców z warstw uprzywilejowanych, czyli w praktyce klas posiadających, do najlepszego wykształcenia, które daje dostęp do najbardziej prestiżowych i dochodowych ról zawodowych. Kapitał kulturowy jest więc przezeń uznawany przede szystkim za narzędzie, dzięki któremu „klasy posiadające” umacniają i stabilizują swoją ekonomicznie zdefiniowaną dominującą pozycję społeczną.

Ta klasyczna zależność nie musi być traktowana jako uniwersalna (zob. szerzej: Zarycki 2008). Niewątpliwie wystepuje ona w tzw. nowoczesnych społeczeństwach zachodnich, gdzie najwyraźniej rozwinęły się podziały klasowe

Adres do korespondencji: t.zarycki@uw.edu.pl 
i gdzie - mówiąc językiem Bourdieu - logika stratyfikacji zdominowana jest najsilniej przez kapitał ekonomiczny, któremu podporządkowane pozostają w dużym stopniu zarówno kapitał kulturowy, jak i polityczny oraz ich elity. Jednak Polska - podobnie jak Rosja i wiele innych krajów Europy Środkowej i Wschodniej - wydaje się społeczeństwem, w którym te wzorcowe Marksowskie zależności działają $\mathrm{w}$ ograniczonym zakresie, $\mathrm{z}$ dwóch powiązanych ze sobą przyczyn. Po pierwsze, kraje te, a w szczególności Polska, mimo przynależności do kręgu cywilizacji europejskiej w dużym stopniu są krajami przednowoczesnymi. Do Polski w ograniczonym zakresie dotarły zarówno procesy modernizacji społecznej, jak i ekonomicznej. Nie doświadczyliśmy raczej towarzyszącego rewolucji francuskiej konfliktu mieszczaństwa ze szlachtą (w szczególności porażki tej ostatniej) ani daleko posuniętej sekularyzacji. W wymiarze ekonomicznym nie doszło nigdy do spektakularnego rozwoju miast, który spowodowałby przekształcenie się rodzimej burżuazji w grupę dominującą ekonomicznie i politycznie, ani do takiego zaawansowania procesu industrializacji (w szczególności przed rokiem 1944), by powstała klasa robotnicza jako kluczowa politycznie grupa społeczna. Pozostały natomiast liczna warstwa chłopska i inteligencja o bardziej postszlacheckim niż mieszczańskim etosie. Można więc mówić o utrzymywaniu się opisywanej przez Stanisława Ossowskiego (1970) „dwuwarstwowości kulturalnej” dzielącej społeczeństwo polskie na postszlacheckie, „kulturalne” elity i „niekulturalny" lud. Jest ona, jak wskazywał Ossowski, znacznie ostrzejsza w Polsce niż w krajach zachodniej lub północnej Europy. Anna Sosnowska wskazuje, że w tym sensie bardziej egalitarne od polskiego są także społeczeństwa ukraińskie, słowackie, litewskie czy bałkańskie, „gdzie wszyscy — mówiąc w skrócie — byli kiedyś chłopami" (Sosnowska 2008, s. 164). Wiąże się to ściśle z faktem peryferyjnego położenia Polski względem głównych potęg gospodarczych i politycznych współczesnego świata. Owa peryferyjność może być w wysokim stopniu uważana za przyczynę ograniczonego zaawansowania wspomnianych wcześniej procesów społecznych i gospodarczych, a także niewykształcenia się w naszym kraju klasycznych podziałów politycznych opisywanych przez zachodnich politologów, $z$ wyjątkiem osi miasto-wieś, ostatnio prawdopodobnie także zmarginalizowanej (Zarycki 2000).

Jednocześnie ów niepełny zakres modernizacji polskiej gospodarki i społeczeństwa w kategoriach oświeceniowych może być uważany za polskiej peryferyjności przyczynę. Niezależnie jednak od tego, jak rozstrzygniemy ten swoisty dylemat sprzężenia zwrotnego między relatywnym zacofaniem a peryferyjnością kraju, gospodarcza peryferyjność Polski jest czynnikiem, który można rozpatrywać jako oddzielną okoliczność kształtującą współczesną strukturę społeczną kraju. Peryferyjność owa może być między innymi odpowiedzialna w perspektywie długiego trwania za niestabilność systemu ekonomicznego. Warto zwrócić uwagę, że jest ona typową cechą krajów peryferyjnych i semiperyferyjnych, rozumianych tak jak definiował je Immanuel Wallerstein (1974) w swojej 
teorii systemu światowego. To one w najwyższym stopniu stają się ofiarą światowych kryzysów na rynkach finansowych i najczęściej załamują się ich systemy gospodarcze, zwłaszcza w wyniku wycofania przez centra zainwestowanych tu kapitałów. Występująca na ziemiach polskich w XX wieku nieciągłość systemu gospodarczego, a szerzej instytucjonalnego, w szczególności systemu walutowego, pokazuje, jak bardzo nasz kraj pasował do tego modelu w ostatnich dwu stuleciach. Jak wiadomo, równie kruche były w ostatnim stuleciu struktury państwowe, w znaczącej części mniej lub bardziej obce, kontrolowane przez zewnętrzne mocarstwa. Podobnie kapitał ekonomiczny na ziemiach polskich był i pozostaje w znacznym stopniu kapitałem obcym. Rodzimi kapitaliści, jak pokazuje wiele przykładów z ostatnich lat, często nie cieszą się długo swoimi fortunami, można nawet powiedzieć, iż raczej je „miewają”, niż przekazują z pokolenia na pokolenie. Ich niespodziewane wzloty i upadki często są uzależnione od związków z równie niestabilnymi elitami politycznymi. Słabość i zmienność struktur politycznych, a przede wszystkim fundamentu nowoczesnych społeczeństw - struktur ekonomicznych i ulotność kapitału ekonomicznego, niezależnie od nowoczesności czy zacofania społeczeństwa, powodują, że kapitał kulturowy i jego elity stają się czynnikiem stabilizującym strukturę społeczną. Najbardziej wyrazistym przejawem dominującej roli tego kapitału w polskim społeczeństwie wydaje się tradycyjnie silna rola inteligencji - reprodukującej się warstwy społecznej nieznanej w krajach zachodnich (Gella 1976).

Nie brak, oczywiście, głosów raz po raz wieszczących zmierzch inteligencji, w szczególności po upadku komunizmu. Wydają się one jednak co najmniej przedwczesne. Istnieniu inteligencji, zarówno w Polsce, jak i w Rosji, od zarania towarzyszą - jak wskazuje na przykład Masha Gessen (1997) - debaty nad jej upadkiem, który zwykle jednak nie następuje. W ostatnim okresie jednym z bardziej spektakularnych przejawów znaczenia inteligenckiego etosu w społeczeństwie polskim był głośny spór o „wykształciuchów” między politykami PO i PiS, z udziałem kibicujących obu partiom publicystów. Ten konflikt symboliczny, zainicjowany przez Ludwika Dorna (2006) odwołującego się do pojęcia wywiedzionego z Sołżenicynowskiej krytyki „nowej” sowieckiej inteligencji (obrazowańszcziny), był doskonałym przykładem roli elit kulturowych w polskim życiu społeczno-politycznym. Ich krytyka ze strony PiS przez wielu została odebrana jako atak polityczny skierowany przeciw inteligencji, przez innych natomiast jako próba delegitymizacji znacznej części jej elit. Spektakularna rola, jaką odegrał w debacie politycznej ten nie pierwszy w Polsce spór o prawa do inteligenckiego przywództwa i kryteria inteligenckości, pokazała, jak kluczowym zasobem w społeczeństwie polskim jest inteligencka tożsamość, a konflikty o dostęp do niej okazują się nie mniej emocjonalne od sporów o przywileje ekonomiczne. Innym dowodem roli inteligencji w społeczeństwie polskim mogą być wyniki uzyskane w badaniu ankietowym przeprowadzonym przeze mnie wśród studentów moskiewskich i warszawskich uczelni pod koniec 2004 r. Ze stwierdzeniem, iż inteligencja „w dużym stopniu dominuje elity 
władzy, nauki, mediów i kultury, nie dopuszczając do nich ludzi «spoza towarzystwa»" w mniejszym lub większym stopniu zgodziło się $60 \%$ studentów ankietowanych w stolicy Polski (w tym 50\% wśród deklarujących się wówczas jako wyborcy Unii Wolności). To samo oskarżenie znalazło już tylko $41 \%$ zwolenników w analogicznej próbie studentów moskiewskich, w której aż $44 \%$ osób było mu przeciwnych (Zarycki 2007). Jednym z pośrednich dowodów istnienia silnego poczucia inteligenckiej dominacji w społeczeństwie polskim prawdopodobnie może być także poparcie, z jakim spotkały się, w szczególności w czasie wyborów 2005 r., antyelitarne i antyinteligenckie hasła polityków Samoobrony, Ligii Polskich Rodzin oraz Prawa i Sprawiedliwości. Najwcześniej i najwyraźniej bunt przeciw inteligenckiej elicie zdefiniował w swojej ofercie programowej Andrzej Lepper, a jego Samoobrona z symbolicznej zemsty na elitach uczyniła przewodni wątek swojego dyskursu wyborczego (Zarycki 2003).

\section{REDEFINICJA ZADAŃ SOCJOLOGII KRYTYCZNEJ W KONTEKŚCIE UPRZYWILEJOWANEJ ROLI KAPITAŁU KULTUROWEGO I POLITYCZNEGO}

W warunkach polskiej peryferyjności kapitał kulturowy wydaje się w wysokim stopniu zasobem pierwotnym $\mathrm{w}$ stosunku do kapitału ekonomicznego i w pewnym stopniu politycznego. Jest on w Polsce kluczowym i najstabilniejszym wyznacznikiem pozycji społecznej w perspektywie procesów długiego trwania. Polskie elity kulturowe cyklicznie tracą i odzyskują zarówno majątki, jak i wpływy polityczne, ale ich uprzywilejowana pozycja znacznie mniej dramatycznie się zmienia, co wynika choćby z samej natury kapitału kulturowego jako zasobu o wydłużonym okresie akumulacji. W najnowszej historii politycznej kraju możemy zauważyć na przykład, że marzec 1968 r. był momentem porażki kapitału kulturowego i jego elit $\mathrm{w}$ starciu $z$ kapitałem politycznym. Ale po tym kryzysie elity kulturowe coraz bardziej związane ze środowiskami opozycyjnymi zaczynały nabierać samodzielności, by w końcowych latach PRL de facto zdelegitymizować ustrój komunistyczny w sferze symbolicznej. Był to ciekawy okres, w którym można obserwować spektakularną autonomię kapitału kulturowego w Polsce. Kluczową rolę jego pola w konfrontacji z władzami komunistycznymi w końcu lat osiemdziesiątych szczegółowo opisał Jan $\mathrm{Ku}-$ bik (1994). Wraz z upadkiem komunizmu opozycyjni inteligenci, podobnie jak w większości krajów regionu, gremialnie weszli do elity politycznej. Jednocześnie, co pokazały między innymi badania zespołu Ivana Szelényiego (1995), nie w pełni uprawnioną okazała się teza o ówczesnym „uwłaszczeniu nomenklatury", którą stawiała między innymi Jadwiga Staniszkis (1991). Dawni członkowie nomenklatury nierzadko zdołali zrobić spektakularne kariery finansowe, ale - mówiąc językiem Bourdieu — konwersja kapitału politycznego w ekonomiczny powiodła się prawie wyłącznie tym członkom dawnego aparatu władzy, którzy jednocześnie byli wyposażeni w znaczące zasoby kapitału kulturowego. Kolejne lata transformacji przyniosły nasilenie się tej tendencji. Wielu drob- 
nych przedsiębiorców stanowiących finansową elitę w schyłkowej fazie PRL, a także tych, którzy zrobili swe majątki tuż po jego upadku, zaczynało tracić grunt pod nogami w coraz silniej globalizującej się polskiej gospodarce. To oni między innymi zasilili szeregi rosnącej wtedy w siłę Samoobrony Andrzeja Leppera. Jednocześnie rosła wyraźnie rynkowa wartość wyższego wykształcenia, a przybywające $z$ coraz większymi kapitałami do Polski międzynarodowe korporacje coraz bardziej atrakcyjne finansowo warunki pracy oferowały najlepiej wykształconym, w szczególności młodszym, mieszkańcom miast, w znacznej części wywodzącym się ze środowisk inteligenckich. Zmiany te spowodowały, $\dot{z}$ e - jak konkludował Henryk Domański (2003, s. 202) po ponad dekadzie od upadku komunizmu — „w hierarchii dochodów kapitały edukacyjny i kulturowy uzyskały prymat nad kapitałem własności”. Należy zwrócić uwagę na pewną paradoksalność tego stwierdzenia. Sparafrazować je bowiem można mówiąc, że inwestowanie $\mathrm{w}$ kapitał ekonomiczny przynosi $\mathrm{w}$ Polsce mniejsze dochody ekonomiczne od inwestycji w kapitał kulturowy, zwłaszcza w jego zinstytucjonalizowanej formie w postaci formalnego wykształcenia. Warto też zwrócić uwagę, że zaobserwowano to w podobnym czasie w większości krajów Europy Środkowo-Wschodniej, ale nie w Rosji. Domański uznał, że tendencje te świadczą o upodabnianiu się społeczeństwa polskiego do społeczeństw zachodnich, ponieważ $\mathrm{w}$ wysoko rozwiniętych krajach europejskich drobni przedsiębiorcy pod względem wysokości dochodów już dawno zostali zdeklasowani przez wykształconych najemnych profesjonalistów pracujących w wielkich korporacjach. Jednak obserwacja ta może także potwierdzać tezę o peryferyjnym charakterze Polski. Marek Ziółkowski (1998, s. 63) twierdzi na przykład, że fakt iż „elitę zarobkową wyznaczają pracownicy wielkich korporacji międzynarodowych, [...] jest zjawiskiem typowym dla krajów Trzeciego Świata".

Można zatem postawić hipotezę o kluczowej w naszym regionie roli kapitału kulturowego jako swoistego substytutu deficytowego kapitału ekonomicznego. Wiąże się z nią teza Eyala, Szelényiego i Townsley (1998) o kompensacyjnej roli inteligencji jako swoistej klasy „kapitalistów kulturowych”, będących substytutem nieobecnej w regionie klasy rodzimych kapitalistów. Jak wiadomo, upadek komunizmu i proces transformacji ekonomicznej w krajach Europy Środkowej skutkował wykupieniem znacznej części majątku narodowego przez kapitał zachodni, którego elity są formalnymi właścicielami znacznej części gospodarek polskiej czy węgierskiej. W Rosji w tym czasie kapitał zagraniczny miał o wiele bardziej ograniczony dostęp do udziałów w najbardziej dochodowych fragmentach gospodarki, zwłaszcza do sektora bankowego i przemysłu wydobywczego. $Z$ tego ostatniego został $z$ resztą $w$ ostatnim okresie prawie całkowicie wyparty przez rosyjskie państwo. Wielkie rosyjskie przedsiębiorstwa w większości są więc własnością obywateli rosyjskich, którzy tworzą o wiele bogatszą niż w Polsce lub na Węgrzech elitę kapitału finansowego. Można zadać pytanie o to, w jakim stopniu dominacja kapitału finansowego nad kulturowym, a w szczególności podrzędna obecnie rola inteligencji w Rosji, wynika 
$\mathrm{z}$ „zacofania” struktury społecznej tego kraju, jak sugeruje to Domański, w jakim zaś $\mathrm{z}$ jego bogactwa (a w szczególności zasobności ekonomicznej jego elity) i względnej ekonomicznej i geopolitycznej niezależności na arenie międzynarodowej. Jednocześnie jednak kapitał ekonomiczny nie może być w Rosji uważany za do końca pierwotny, ponieważ zwłaszcza po dojściu do władzy Władimira Putina oczywiste stało się, że dostęp do niego warunkowany jest ściśle przez posiadanie kapitału politycznego. Posiadanie znaczącego kapitału ekonomicznego jest we współczesnej Rosji ściśle uzależnione od woli struktur państwowych, w szczególności służb specjalnych, których przedstawiciele niejako $\mathrm{z}$ urzędu zasiadają $\mathrm{w}$ większości zarządów przedsiębiorstw działających na terenie kraju (Mereu 2008). Jak najwymowniej pokazał los Michaiła Chodorkowskiego, mogą oni w każdej chwili pozbawić zasobów finansowych nawet najbardziej zamożnych przedsiębiorców. Eyal, Szelenyi i Townsley (1998) pisali w tym kontekście o Rosji jako kraju „kapitalistów bez kapitalizmu”. Kraje Europy Środkowej, jak Polska czy Węgry, określali zaś jako budujące „kapitalizm bez kapitalistów" (między innymi ze względu na wspomnianą słabość lokalnych kapitałów).

Jak się wydaje, zwrócenie uwagi na rolę kapitału kulturowego w społeczeństwach takich jak polskie czy węgierskie i kapitału politycznego w społeczeństwach takich jak rosyjskie czy białoruskie może być jednym ze sposobów adaptacji założeń klasycznej socjologii krytycznej do warunków naszej części Europy. Te właśnie wymiary nierówności społecznych odgrywają tu bowiem, jak się wydaje, rolę, jeśli nie kluczową czy pierwotną w stosunku do nierówności ekonomicznych, to na pewno relatywnie znacznie większą niż w społeczeństwach zachodnich. Takie wskazanie na rolę innych wymiarów nierówności społecznych może być potraktowane jako kontekstualizacja krytyki problemów społeczno-politycznych społeczeństw, które z zachodniego punktu widzenia możemy uznawać za peryferyjne. Można więc w następujący sposób sformułować zalecenie dla socjologii krytycznej społeczeństw peryferyjnych. Po pierwsze, jak wskazywał już Nicos Mouzelis (1986), nie odwołując się jednak jeszcze do teorii Bourdieu, ponieważ na peryferiach inne wymiary organizacji społecznej niż pole ekonomiczne mogą mieć dominującą bądź szczególnie uprzywilejowaną rolę, to poszukując kluczowych aspektów nierówności społecznych, w tym dominacji symbolicznej, powinno się na nie zwracać szczególnie baczną uwagę. Mouzelis, podobnie jak Bourdieu (1980), posługiwał się w tym kontekście pojęciem zróżnicowanych sposobów dominacji (modes of domination). Gdy zatem w krajach „centralnych" podstawowym typem dominacji byłaby dominacja ekonomiczna, w krajach peryferyjnych uprzywilejowane byłyby w szczególności dominacja polityczna i różne, opisywane przez Bourdieu, typy dominacji kulturowej. Warto zwrócić uwagę, że ta ostatnia może przybierać bardzo różne formy, niekoniecznie zdefiniowane w sferze „zinstytucjonalizowanego kapitału kulturowego", na którą szczególną uwagę zwracali Eyal, Szelenyi i Townsley (1998), w dużym stopniu lekceważąc rolę etosu inteligenckiego i siłę swo- 
istego „kapitału moralnego”, którym oprócz inteligencji posługuje się z dużym powodzeniem między innymi Kościół i związane z nim środowiska. Gil Eyal (2003) w swojej późniejszej pracy wyróżnił na przykład dwie podstawowe strategie dyskursywne dominacji symbolicznej elit liberalnych i konserwatywnych w krajach postkomunistycznych. Te pierwsze skupione są na swoiście „duszpasterskim" moralistycznym podejściu do społeczeństwa, które zmusza się do symbolicznego „rachunku sumienia” za zbiorowe grzechy epoki komunizmu, drugie operują tonem bardziej „prokuratorskim”, domagając się kary dla konkretnych winnych przestępstw w okresie komunistycznym, w szczególności tych ujawnionych $w$ wyniku lustracji mającej wzmocnić symboliczny status „ofiar komunizmu”. W obu przypadkach silne są jednak symboliczne aspekty dążenia do dominacji, $w$ wysokim stopniu zdefiniowanej $\mathrm{w}$ wymiarze wyższości moralno-kulturowej, która według Eyala istotną rolę odgrywa zarówno w Czechach, jak i Polsce oraz na Węgrzech.

\section{POMIJANIE KULTUROWEGO WYMIARU NIERÓWNOŚCI NA PERYFERIACH JAKO FORMA „ORIENTALIZMU”}

Przyjęcie powyższych założeń nie oznacza oczywiście, że badacz nastawiony „krytycznie” może lekceważyć nierówności ekonomiczne, zwłaszcza jeśli wykraczają one poza akceptowane przezeń ramy. Istotne wydaje się jednak, by był wyczulony na te wymiary nierówności, które z punktu widzenia statusu społecznego mogą być w społeczeństwach peryferyjnych nie mniej ważne od pola ekonomicznego. Często owe pola nieekonomiczne mogą zresztą wskazywać na korzenie nierówności ekonomicznych w społeczeństwach peryferyjnych. Przykłady Polski i Rosji w jakimś stopniu potwierdzają taką hipotezę. W Polsce to kapitał kulturowy okazuje się dziś kluczowym czynnikiem warunkującym sukces finansowy, w Rosji zaś znacząca większość wielkich fortun, a także mniejszych majątków, wydaje się silnie uwarunkowana przez odpowiednie koneksje polityczne (kapitał polityczny). Lekceważenie znaczenia tych kluczowych dla krajów peryferyjnych wymiarów organizacji społecznej i skupianie się na klasycznej analizie klasowej, nie zawsze w pełni adekwatnej do danego kontekstu, można nazwać „ekonomizacją peryferii przez centrum” lub „ekonomizacją peryferii językiem centralnym”. Innymi słowy, mamy w takich sytuacjach do czynienia ze stosowaniem przez obserwatorów z centrum (bądź peryferyjnych obserwatorów odwołujących się do "centralnych" schematów pojęciowych) własnych schematów poznawczych do opisu niekoniecznie odpowiadającej im rzeczywistości społecznej ${ }^{1}$. W skrajnym przypadku możemy takie opisy oskarżać, za Edwardem Saidem (2005), o grzech orientalizmu. W szczególności typową, według niego, tendencją przejawiającą się niekiedy

\footnotetext{
${ }^{1}$ Ciekawym studium napięcia między „centralnymi” i „peryferyjnymi” schematami opisu rzeczywistości społecznej w Polsce jest artykuł Anny Sosnowskiej (1997).
} 
w omawianych wizjach społeczeństw Europy Środkowej i Wschodniej jest postrzeganie kulturowych odmienności i tożsamości w społeczeństwach peryferyjnych jako „nieracjonalnych”, a więc w wysokim stopniu możliwych do pominięcia $\mathrm{w}$ naukowych analizach. Na takie tendencje zwracali już uwagę między innymi József Böröcz (2000) i Michał Buchowski (2006), oskarżając niektórych intelektualistów z Europy Środkowo-Wschodniej o swoistą „samoorientalizację", związaną z odmową prawa do uznawania działań społecznych i politycznych mniej uprzywilejowanych współobywateli za „racjonalne”. W dyskursie krytykowanym przez wspomnianych autorów charakterystyczny jest podział interesów i konfliktów na „rzeczywiste” i „zastępcze” czy na „realne” i „fałszywe” bądź „urojone”. Te pierwsze zdefiniowane są w kategoriach ekonomicznych, pozostałe - najczęściej w kategoriach kulturowych, a w szczególności tożsamościowych, i zwykle w takim ujęciu są traktowane jako wynik „zagubienia” mieszkańców krajów regionu - bądź to w wyniku panujących tam zaściankowych tradycji, bądź manipulacji elit ekonomicznych chcących sprowadzić debaty polityczne na niegroźne dla nich kwestie.

Przykładem obrazów społeczeństwa polskiego, wobec których można wysuwać podobną krytykę mogą być prace takich autorów jak David Ost czy Daniel Beauvois. Tego ostatniego zdumiewa fakt, że w Polsce nawet potomkowie chłopów i robotników wybierają tradycję ziemiańską, wstydząc się własnej (Beauvois 2006). Innymi słowy, krytykuje on polską koncepcję obywatelstwa opartą na idei powszechnej nobilitacji i rozszerzenia ideałów równości szlacheckiej z okresu I Rzeczypospolitej na wszystkich członków narodu. Wtóruje mu Bronisław Łagowski (2007) sugerujący, iż „lud wyszedł z historii, wstydząc się swojej tożsamości. Tym łatwiej przyjmował mitologię, poglądy, samoświadomość klasy, która go uciskała". Według tych autorów, osadzone w historii polskie spory polityczne, $w$ dużej mierze dotyczące praw do kulturowo zdefiniowanego statusu uprzywilejowania, powinny zostać zastąpione przez konflikty ekonomiczne, dla których punktem odniesienia są podziały społeczne i historia krajów Europy Zachodniej. Pozytywne odwołania do mitów Rzeczypospolitej przedrozbiorowej za nieprawomocne - podobnie jak Beauvois, podkreślający kulejącą praktykę „szlacheckiej demokracji” — uważa Andrzej Romanowski (2008), wskazujący między innymi na rokosze szlacheckie, rzezie w czasie powstania Chmielnickiego czy ogólne zacofanie kraju w stosunku do Zachodu jako zjawiska ten okres historii naszego kraju całkowicie dyskredytujące jako źródło pozytywnych odwołań tożsamościowych.

Najbardziej systematyczną teorię swoistej „fałszywej świadomości” polskich klas niższych rozwinął ostatnio David Ost w przetłumaczonej już na język polski Klęsce Solidarności (2007). Sugeruje on między innymi, iż polscy robotnicy nie są w stanie walczyć o swoje „obiektywne” interesy ekonomiczne, ponieważ podsuwa się im „zastępcze” problemy „tożsamościowe”. Jak słusznie wskazuje między innymi Adam Leszczyński, postulat Osta - zastąpienia w Polsce polityki tożsamościowej polityką klasową — ignoruje naszą tradycję polityczną, 
która zawsze częściej odwoływała się do wspólnot symbolicznych niż do interesów klasowych (Leszczyński 2005). Co więcej, tożsamości kulturowe w szczególności postszlachecka tożsamość inteligencka, do której aspirują szerokie rzesze wywodzących się ze wsi i rodzin robotniczych „wykształciuchów” - w kontekście polskim stanowią dość wymierny zasób społeczny. Jest on nie tylko źródłem prestiżu, ale i stymulatorem aspiracji społecznych, w szczególności edukacyjnych, a także poczucia obywatelskiej odpowiedzialności. Jednocześnie, jak wykazały to badania, stanowi kluczowy komponent kapitału kulturowego, który jest zasobem warunkującym w Polsce dostęp do wyższego wykształcenia, a więc i awansu społecznego, w sposób skuteczniejszy od ścieżki polegającej na bezpośrednim dążeniu do zdobycia kapitału ekonomicznego. Jak wspomniano, kapitał kulturowy jest w warunkach polskiej peryferyjności zasobem o wiele stabilniejszym od kapitału ekonomicznego, a także politycznego. Proponowanie, by Polacy skupili się $\mathrm{w}$ swoim życiu politycznym wyłącznie na interesach ekonomicznych, a odrzucili między innymi spory o prawo do statusu inteligenckiego, o demokratyzację dostępu do kapitału kulturowego i symbolicznego, oznacza więc przede wszystkim wezwanie, by wielu z nich zignorowało swoje kluczowe, najstabilniejsze zasoby społeczne.

Ponadto pominięcie kwestii sporów tożsamościowo-kulturowych w dyskursie politycznym oznacza abstrahowanie od kluczowego wymiaru nierówności społecznych, w dużym stopniu przesądzającego o kształcie nierówności ekonomicznych. Co najmniej bowiem dopóki gospodarka polska będzie gospodarką peryferyjną, a państwo polskie państwem słabym, dopóty elity będą w nim definiowane przede wszystkim w kategoriach kulturowo-tożsamościowych, choćby taka sytuacja krytykom społeczeństwa polskiego wydawała się „nienormalna”. Ignorowanie nierówności tożsamościowo-kulturowych $\mathrm{w}$ sferze debaty politycznej nie zmniejszy siły ich oddziaływania, a w pewnych aspektach może mieć efekt wzmacniający. Ich mechanizmy bowiem mogą stać się w takim kontekście jeszcze bardziej znaturalizowane i niewidoczne, a więc trudniejsze do poddania krytyce.

Można chyba przy tym polemizować z Ostem co do jego twierdzenia, iż wykluczenie ekonomiczne jest zawsze mniej dramatyczne od wykluczenia tożsamościowego. Sugerował on bowiem, iż scena polityczna zorganizowana wokół sporów czysto ekonomicznych wytwarza o wiele bardziej obywatelskie społeczeństwo od sceny politycznej, na której kluczową rolę ogrywają konflikty kulturowe. Istnieją przykłady wskazujące na odmienne skutki opisywanej konfiguracji konfliktów politycznych. Przypomnijmy sobie rewolucję bolszewicką $z$ jej ideologią odbierającą prawa społeczne, a często i prawo do życia, głównie na podstawie statusu ekonomicznego. Jednocześnie spory tożsamościowe wcale nie muszą przybierać niecywilizowanych postaci i prowadzić do nienegocjowalnych wykluczeń. Jako przykład można podać wiele państw wielokulturowych, wielonarodowych i wielowyznaniowych, które są w stanie kanalizować napięcia tożsamościowe: jak choćby Szwajcaria ze współistniejącymi w niej 
różnojęzycznymi kantonami czy Holandia, w której przez kilka dziesięcioleci w sposób demokratyczny negocjowano stosunki międzywyznaniowe. Los zaś wykluczanych dyskursywnie w Polsce ze wspólnoty narodowej przez skrajną prawicę liberalnych inteligentów oskarżanych o kosmopolityzm nie wydaje się aż tak dramatyczny w porównaniu na przykład z losem milionów obywateli Stanów Zjednoczonych w praktyce wykluczonych z życia społecznego w teoretycznie o wiele bardziej „cywilizowanym” wymiarze ekonomicznym. Niezależnie od tego, który z wymiarów podziału społeczeństwa przypada nam bardziej do gustu, w przypadku polskim różnice w wymiarze kapitału kulturowego wydają się osią hierarchizacji społeczeństwa, której jego krytyczni badacze lekceważyć nie mogą. Jeżeli zaś tak jest, to od krytycznej socjologii w nie mniejszym stopniu należałoby oczekiwać wskazywania dróg demokratyzacji dostępu do kapitału kulturowego niż do kapitału ekonomicznego. Wydaje się bowiem, iż sugerowana między innymi przez Osta teza, że poparcie dla partii prawicowych i ruchów odwołujących się to tradycyjnych ram kulturowych w Polsce jest głównie efektem „tożsamościowego skanalizowania” frustracji powstałych na tle marginalizacji ekonomicznej, jest w znacznym stopniu nieuzasadniona. Poparcie dla programów wzmocnienia polskiej tradycyjnej tożsamości narodowej, ograniczenia wpływów liberalnych elit inteligenckich czy dowartościowywania tradycji religijnych $\mathrm{w}$ dużym stopniu jest związane z potrzebą uznania, dowartościowania kapitału symbolicznego znacznych segmentów społeczeństwa naznaczonych przez poczucie kulturowej marginalizacji. Owa potrzeba uznania w sferze kulturowej w większości przypadków, jak się wydaje, nie może być kompensowana całkowicie przez li tylko poprawę położenia omawianych grup w wymiarze ekonomicznym. Zresztą ze względu na wspomnianą wcześniej niestabilność systemu politycznego i ekonomicznego w naszej peryferyjnej rzeczywistości nawet znaczne transfery finansowe grupom nie wyposażonym w poważniejsze zasoby kapitału kulturowego raczej nie zapewnią trwałego awansu społecznego.

\section{KULTUROWE UWARUNKOWANIA I OGRANICZENIA UPRAWIANIA SOCJOLOGII KRYTYCZNEJ NA PERYFERIACH}

Uprawianie socjologii krytycznej $\mathrm{w}$ warunkach polskich nie jest zadaniem łatwym, jak zwrócił uwagę Andrzej Rychard (2007), i to nie tylko ze względu na złożoność sytuacji społecznej $\mathrm{w}$ porównaniu $\mathrm{z}$ modelami analizowanymi w zachodnich naukach społecznych. Istotną barierę stanowi także ryzyko niezamierzonych a trudnych do uniknięcia bieżących uwikłań politycznych, wspomniane też przez Rycharda. W szerszym kontekście teoretycznym należy zwrócić uwagę, że spośród trzech wymienionych tu typów hierarchii społecznej: ekonomicznego, politycznego i kulturowego, ten ostatni stwarza szczególne wyzwania dla socjologii krytycznej. W przypadku dominacji kapitału ekonomicznego i politycznego, a więc elit ekonomicznych i politycznych, socjolo- 
gowie, zwykle do tych elit nie należący, odnoszą się do zewnętrznych grup społecznych, których dominację często odczuwają nie mniej wyraźnie od większości podporządkowanych grup społecznych. Jeśli jednak mamy do czynienia z uprzywilejowaniem kapitału kulturowego i tak czy inaczej zdefiniowanych elit kulturowych, to wypowiedź socjologa najczęściej będzie jednocześnie samokrytyką grupy czy grup do której należą sami krytycy. Uprawiający socjologię wchodzą bowiem mimowolnie w kluczowe obszary pola intelektualnego i kulturowego, a zatem nawet gdy temu zaprzeczają, angażują się we współzawodnictwo o pozycję społeczną w jego sferze. Zygmunt Bauman (1992) zauważył, że każda próba definicji intelektualisty jest $\mathrm{w}$ istocie próbą samodefinicji, podobnie dzieje się $\mathrm{w}$ przypadku sporów o definicję inteligenta oraz krytyki ról społecznych intelektualistów czy inteligencji - w mniejszym lub większym stopniu zawsze jest to samokrytyka. Ten stan rzeczy oznacza, że krytyka roli struktur kapitału kulturowego w społeczeństwie je uprzywilejowującym może być odczytywana nie tylko jako atak na kluczowe dla danego kraju/społeczeństwa zasoby symboliczne, ale także jako podważanie statusu własnej grupy przez osobę taką krytykę przedstawiającą.

Historia środkowo- i wschodnioeuropejskiej socjologii naznaczona jest zresztą przez dziesiątki nazwisk krytyków inteligencji, i szerzej: elit kulturowych, którzy nierzadko byli oskarżani o naruszanie uznanych wartości. Wymienić tu można choćby kanoniczną krytykę inteligencji Józefa Chałasińskiego (1946) czy wspomnianą wcześniej krytykę inteligencji sowieckiej przez Sołżenicyna. Być może więc sytuacja krytyka społeczeństwa o dominującej roli kapitału kulturowego może być w pewnych aspektach uważana za trudniejszą, a nawet bardziej ryzykowną, od roli krytyków społeczeństw, w których dominuje kapitał ekonomiczny czy polityczny. Tam bowiem narażenie się dominującym strukturom może być kompensowane przez dowartościowanie we własnym polu kapitału kulturowego. Krytyka dominacji kapitału kulturowego może natomiast implikować wykluczenie $z$ jego pola bez szans na kompensację na polach alternatywnych, zwykle traktujących inteligentów czy intelektualistów jako $z$ definicji obcych.

W krajach o uprzywilejowanej roli kapitału kulturowego szczególnie ważnym elementem teorii krytycznej, uwypuklanym jako nieodzowny komponent przez wszystkich jej klasyków, na czele z Bourdieu, wydaje się więc uświadomienie sobie przez krytyków własnej zależności od struktur społecznych ograniczających działanie. Bourdieu sugeruje w szczególności, iż socjologia krytyczna powinna zawierać element własnej socjologii, a „wszystkie tezy tworzone przez taką naukę powinny także być odnoszone do osób, które ją praktykują" (Bourdieu 1987). Krytyka społeczeństwa peryferyjnego o dominacji kapitału kulturowego powinna być zatem także krytyką tworzących ją elit owego kapitału. Craig Calhoun zwraca uwagę na konieczność uwzględniania przez socjologię krytyczną jej własnej historyczności i nieuniknionego zaangażowania w świat „realnych” interesów. Nieco dalej na kartach swojej Critical Social 
Theory Calhoun proponuje podstawowe „reguły” krytycznej socjologii. Przede wszystkim jest to krytyczne zaangażowanie we współczesny dla autora świat społeczny, opierające się na przeświadczeniu, że istniejący stan rzeczy w życiu społecznym nie wyczerpuje wszystkich możliwości. Jednocześnie socjologię krytyczną cechować powinna, według Calhouna, świadomość historycznych i kulturowych uwarunkowań, od których zależy działalność intelektualna jej twórcy (Calhoun 1995). W społeczeństwach peryferyjnych owe uwarunkowania wydają się $\mathrm{W}$ większym stopniu określone przez sieci kapitału kulturowego czy politycznego niż w silniej „zekonomizowanych” krajach centrum systemu światowego.

Jeśli więc powyższe założenia są uzasadnione, to socjologia krytyczna w krajach zachodnich, w szczególności Stanach Zjednoczonych, w wysokim stopniu skupiająca się na nierównościach ekonomicznych, w Polsce powinna zwracać szczególną uwagę na nierówności kulturowe, w Rosji zaś na nierówności polityczne. Te wymiary mogą być też uważane za istotne struktury warunkujące, a w skrajnych przypadkach ograniczające, działalność socjologów w tych krajach i ważne aspekty postulowanej przez Bourdieu „socjologii socjologii”. W szczególności tam gdzie kapitał kulturowy i inteligencja ogrywają znaczącą rolę, krytycy jego struktur mogą być oskarżani o osłabianie pozycji kraju na arenie międzynarodowej, na przykład przez podważanie prestiżu kultury narodowej, niszczenie obrazu elit i autorytetów, których dorobek kulturowy stanowi ważny zasób kompensujący słabość lokalnego kapitału oraz własnego państwa. Analogicznie w krajach o dominacji kapitału politycznego krytyka roli struktur państwowych, roli elity politycznej itp. może powodować oskarżanie badaczy o osłabianie państwa, w którym silna władza musi kompensować uzależnienie od krajów zachodnich. Rosja dostarcza dziś bardzo wielu przykładów takiej prawidłowości. Prezydent Putin niedawno nazywał „szakalami” krytycznych wobec Kremla liberalnych inteligentów korzystających z zachodnich grantów i dotacji. W Polsce znanym krytykiem liberalnej rosyjskiej inteligencji jako formacji osłabiającej państwowość rosyjską jest Andrzej Walicki (2004), który oskarża ją o co najmniej nieodpowiedzialność i lekceważenie rosyjskich tradycji i interesów narodowych. W Polsce, gdzie w przeciwieństwie do Rosji większość inteligenckich elit opowiada się za pogłębianiem integracji z systemem światowym, ich krytyka właśnie za udział w legitymizacji włączenia w globalny system ekonomiczny kraju o zdecydowanie zliberalizowanej gospodarce $z$ wyraźnym uprzywilejowaniem interesów wielkiego kapitału może się wiązać z ryzykiem otrzymania etykiety elementu antyzachodniego, co niesie za sobą obniżenie w kluczowym w polskich warunkach wymiarze statusu kulturowo-społecznego, choć może być jednocześnie nagrodzone w niektórych segmentach pola politycznego, jednak o niewielkiej wartości dla uczonych.

Kluczowym aspektem roli polskiej elity kulturowej jest, jak się wydaje, funkcja pośrednika w transmisji wzorów zachodnich, czyli swoistego gwaranta przynależności kraju do cywilizacji Zachodu. Być może to dlatego właśnie nie- 
nowe wcale oskarżenie liberalnych inteligenckich elit o zdradę interesów robotniczych po 1989 r. w poważnej, akademickiej cytowanej tu już pracy pt. Klęska Solidarności po raz pierwszy opublikował właśnie Amerykanin David Ost. Być może dlatego także Anglik Ken Loach nakręcił pierwszy film o wyzysku polskich pracowników w Wielkiej Brytanii - Polak potrzebny od zaraz. Nie są oni bowiem uwikłani w ograniczenia polskich sieci kapitału kulturowego i nie ryzykują deprecjacji własnego statusu, nie muszą też wykazywać nobilitujących związków z kulturą zachodnią jako jej nosiciele. We wstępie do pracy Elizabeth Dunn na temat społecznych aspektów prywatyzacji w Polsce sam Ost (2008) zresztą zwrócił uwagę, że po 1990 r. Polacy byli rozczarowani jego nadmierną wiedzą o naszym kraju, bo „potrzebowali Amerykanina uczącego ich «normalnego» sposobu życia w Ameryce”. Jednocześnie postawił tezę, iż polscy naukowcy społeczni nie prowadzą badań uczestniczących losów przegranych polskiej transformacji, ponieważ „polscy intelektualiści wciąż cieszą się zbyt wysokim prestiżem społecznym, aby pozwolić sobie na tego rodzaju pracę". Być może jest to diagnoza częściowo słuszna - wielu autorów, począwszy co najmniej od Chałasińskiego, zwracało uwagę na często odczuwaną w środowiskach inteligenckich presję konieczności podkreślania swojej odrębności od „ludu”. Osobiście uważam, że istotny wpływ na rezerwę wobec teorii krytycznej w środowiskach polskiej inteligencji ma rola, jaką kultura zachodnia pełni $\mathrm{w}$ legitymizacji inteligenckiego statusu. Inteligent jako pośrednik między cywilizacją zachodnią a własnym społeczeństwem często podświadomie stara się nie narażać na podważenie swojego statusu reprezentanta wartości i kompetencji świata zachodniego, co mogłoby nastąpić w wyniku nadmiernie radykalnej krytyki przyjmowanych z Zachodu rozwiązań społeczno-gospodarczych. Także w obecnie obserwowanej fali zainteresowania teorią krytyczną, której znanym przykładem są działania środowiska „Krytyki Politycznej”, można zauważyć głównie zapożyczenia ze współczesnej lewicowej myśli zachodniej, przy małym zainteresowaniu spuścizną rodzimą. Rafał Matyja (2007) zauważa, że takie odwołanie do teorii zachodniej „wygląda modnie i daje poczucie uczestnictwa w czymś ważniejszym niż jakiś prowincjonalny polski spór".

Można także zwrócić uwagę na rolę geopolitycznego myślenia polskich elit inteligenckich, które za istotne zagrożenie dla Polski w dalszym ciągu uważają Rosję (Zarycki 2004), a jedną z konsekwencji tego jest dowartościowanie wszelkich kontaktów z szeroko rozumianym Zachodem. W logice związanej z takim postrzeganiem priorytetów geopolitycznych kraju można także doszukać się w ostatnich dwu dekadach przekonania o konieczności względnie ugodowej postawy wobec państw zachodnich, a w szczególności ich elit ekonomicznych, które będą Polsce gwarantować bezpieczeństwo w sytuacji wschodniego zagrożenia. Ceną za nie jest niejako zgoda na dość radykalnie liberalne rozwiązania społeczno-gospodarcze, których oczekują zachodnie koła gospodarcze. Byłaby to sytuacja odwrotna do tej, jaka w większości krajów Zachodu panowała do upadku Związku Sowieckiego. Wtedy bowiem zagrożenie komunistyczne ze 
Wschodu implikowało zgodę zachodnich elit na poszerzanie sfery socjalnej w celu ograniczenia pokus stwarzanych przez sowiecką agitację. Dziś jednak, gdy kluczowe segmenty polskiej gospodarki znajdują się w rękach zachodnich, konsekwentne stosowanie zasad lewicowej krytyki społecznej musiałoby oznaczać w znacznym stopniu krytykę zachodniego kapitalizmu, a więc wystawiałoby krytykujących na ryzyko utraty statusu symbolicznego reprezentanta Zachodu, a nawet narażało na oskarżenia o nacjonalizm. Warto zwrócić uwagę, że dylemat ten: napięcie między konsekwentną krytyką zachodnich kapitalistów kontrolujących znaczą część polskiej gospodarki a aspiracjami do statusu ekspertów w sprawie modernizacji Polski na wzór zachodni, a więc reprezentantów Zachodu i jego interesów, w historii polskiej myśli krytycznej pojawiał się już wcześniej. Można jednocześnie zauważyć, że nie dotyczy to krytyki roli kapitału ekonomicznego wywodzącego się ze Wschodu, w szczególności rosyjskiego, który - na co panuje dość powszechna zgoda - należy kontrolować.

Można więc sądzić, że obecnie jesteśmy świadkami nasilania się procesu redefinicji i renegocjacji języka, w jakim w Polsce będziemy opisywać nasze stosunki z szeroko rozumianym Zachodem oraz nasze odrębne $\mathrm{w}$ stosunku do niego interesy. Innymi słowy, toczy się debata co do wyznaczenia nowych granic głównego nurtu dyskursu politycznego, w szczególności języka krytycznego, w którym zostanie określona akceptowalna powszechnie przestrzeń dyskursywna między biegunami nacjonalizmu a kosmopolityzmu. Już dziesięć lat temu Marek Ziółkowski (1998, s. 61) pisał, iż „podstawowym dylematem polskiego państwa i społeczeństwa jako całości jest szukanie «złotego środka» między, $z$ jednej strony, pełnym otwarciem, uczestnictwem w światowym systemie kapitalistycznym i jego ponadnarodowych organizacjach, poddawaniem się jego wpływom, chłonięciem jego gospodarczych, politycznych i kulturowych wzorów, a $z$ drugiej strony - częściowym choćby zamknięciem, próbą zachowania niezależności gospodarczej, obroną tradycji i dalszym rozwijaniem własnej odrębnej kultury narodowej, co jest oczywiście także reakcją na globalizacje”". Jak się wydaje, kwestia wyznaczania granicy między zarysowanymi przez Ziółkowskiego biegunami obecnie nabiera coraz większej dynamiki.

\section{NIEZBĘDNOŚĆ STRUKTUR KOMPENSUJĄYCH}

Krytykując Polskę i Rosję, tak jak inne społeczeństwa krajów peryferyjnych o analogicznych odmiennościach w hierarchii kapitałów, z powodu panujących $\mathrm{w}$ nich nierówności w kluczowych dla nich wymiarach, należy pamiętać, że wymiary owe, choć mogą być źródłem budzącej krytykę czy wręcz oburzenie symbolicznej dominacji elit danych społeczeństw, wykluczenia i innych uznawanych przez nas za niesprawiedliwe różnic, zwykle pełnią $\mathrm{w}$ danych krajach istotne funkcje strukturalne. Są źródłem historycznej ciągłości narodów, spójności społecznej, stanowią podstawową ramę odniesienia dla społecznej organizacji, a w szczególności strukturyzacji dyskursu publicznego. Pozbycie się 
owych ram, mechaniczne próby wprowadzenia klasycznych struktur organizacji „nowoczesnych” społeczeństw zachodnich, w szczególności zbyt radykalne próby działań $\mathrm{w}$ takim kierunku, mogą prowadzić do zaburzenia społecznej równowagi i do wielu wynikających z tego niebezpiecznych, a niekiedy wręcz tragicznych w swoich konsekwencjach procesów. Owe alternatywne do ekonomicznego kapitały mogą być bowiem rozpatrywane jako substytuty peryferyjnej słabości i zależności. Pozbawione ich społeczeństwa, nawet jeśli deprywacja miałaby tylko wymiar symboliczny, niezależnie od ewentualnych zysków, rozumianych na przykład jako „postęp na drodze modernizacji”, straciłyby istotne zasoby, w szczególności kluczowe atuty i źródła poczucia godności w stosunkach z silniejszymi aktorami na scenie międzynarodowej. Domagając się „normalizacji" społeczeństw peryferyjnych, upodobnienia ich struktur do tych opisywanych w „nowoczesnych” krajach zachodnich, musimy pamiętać o takich właśnie możliwych negatywnych skutkach. Można tu odwołać się do znanej refleksji Anthony'ego Giddensa na temat roli struktur społecznych, którą przedstawił on w swojej teorii strukturacji (Giddens 2003). Z jednej strony są one czynnikami utrudniającymi działanie, konstytuującymi wszelkie nierówności, dzielącymi społeczeństwa i grupy społeczne. $Z$ drugiej strony wszelkie struktury są niezbędnymi elementami jakiegokolwiek działania społecznego, które odwoływać musi się do wspólnych dla całego społeczeństwa ram. Bez nich niemożliwe jest istnienie społeczeństwa, jego ewolucja i komunikacja między jego członkami. Krytycy dominacji symbolicznej w polu politycznym czy kulturowym tej ambiwalencji roli zastanych struktur w krajach peryferyjnych muszą być zawsze świadomi.

\section{BIBLIOGRAFIA}

Bauman Zygmunt, 1992, Love in Adversity: On the State and the Intellectuals, and the State of the Intellectuals, „Thesis Eleven”, t. 31, s. 81-104.

Beauvois Daniel, 2006, Kresomania. Wywiad z Danielem Beauvois, „Tygodnik Powszechny”, 26 marca.

Böröcz József, 2000, Informality Rules, „East European Politics and Societies”, t. 14, s. 348-380.

Bourdieu Pierre, 1986, The Forms of Capital, w: Handbook of Theory and Research for Sociology of Education, John G. Richardson (red.), Greenwood Press, New York.

Bourdieu Pierre, 1980, Le sens pratique, Éditions de Minuit, Paris.

Bourdieu Pierre, 1987, Choses dites, Éditions de Minuit, Paris.

Bourdieu Pierre, 2005, Reprodukcja. Elementy teorii systemu nauczania, tłum. Elżbieta Neyman, Wydawnictwo Naukowe PWN, Warszawa.

Buchowski Michał, 2006, The Specter of Orientalism in Europe: From Exotic Other to Stigmatized Brother, „Anthropological Quarterly”, t. 79, s. 463-482.

Calhoun Craig J., 1995, Critical Social Theory: Culture, History and the Challenge of Difference, Blackwell, Cambridge, Mass.

Chałasiński Józef, 1946, Społeczna genealogia inteligencji polskiej, Czytelnik, Warszawa.

Domański Henryk, 2003, Kryzys inteligencji a sfera publiczna, „Krytyka Polityczna”, nr 3. 
Dorn Ludwik, 2006, Krytykuje nas rojowisko histeryków. Wywiad z Ludwikiem Dornem, „Dziennik”, 26 sierpnia.

Eyal Gil, 2003, The Origins of Postcommunist Elites: From Prague Spring to the Breakup of Czechoslovakia, University of Minnesota Press, Minneapolis.

Eyal Gil, Szelényi Iván, Townsley Eleanor R., 1998, Making Capitalism without Capitalists: Class Formation and Elite Struggles in Post-Communist Central Europe, Verso, London-New York.

Gella Aleksander, 1976, An Introduction to the Sociology of the Intelligentsia, w: Aleksander Gella (red.), The Intelligentsia and the Intellectuals. Theory, Method, and Case Study, Sage, Beverly Hills, Cal.

Gessen Masha, 1997, Dead Again: The Russian Intelligentsia after Communism, Verso, London-New York.

Giddens Anthony, 2003, Stanowienie społeczeństwa. Zarys teorii strukturacji, tłum. Stefan Amsterdamski, Zysk i S-ka, Poznań.

Kubik Jan, 1994, The Power of Symbols Against the Symbols of Power: The Rise of Solidarity and the Fall of State Socialism in Poland, Pennsylvania State University Press, University Park, Pa.

Leszczyński Adam, 2005, Samobójstwo liberatów, „Gazeta Wyborcza”, 28 grudnia.

Łagowski Bronisław, 2007, Niemy lud polski. Wywiad z Bronisławem Łagowskim, „Gazeta Wyborcza", 3 listopada.

Matyja Rafał, 2007, Zapomniana tradycja. O słabości polskiej myśli lewicowej, „Europa”, nr 49.

Mereu Francesca, 2008, Putin Made Good on Promise to FSB, „Moscow Times”, 8 lutego.

Mouzelis Nicos P., 1986, Politics in the Semi-periphery: Early Parliamentarism and Late Industrialisation in the Balkans and Latin America, St. Martin's Press, New York.

Ossowski Stanisław, 1970 [1944], O drogach upowszechniania kultury umystowej na wyższym poziomie, w: Dzieta, t. 6, PWN, Warszawa.

Ost David, 2007, Klęska „Solidarności”. Gniew i polityka w postkomunistycznej Europie, tłum. Hanna Jankowska, Muza, Warszawa.

Ost David, 2008, Wstęp, w: Elizabeth C. Dunn (red.), Prywatyzując Polskę. O bobofrutach, wielkim biznesie $i$ restrukturyzacji pracy, tłum. Przemysław Sadura, Wydawnictwo Krytyki Politycznej, Warszawa.

Romanowski Andrzej, 2008, Majsterkowicze naszej pamięci (2), „Gazeta Wyborcza”, 14 marca.

Rychard Andrzej, 2007, Parę refleksji o trudnościach tworzenia krytycznej socjologii postkomunizmu, „Studia Socjologiczne”, nr 1.

Said Edward W., 2005, Orientalizm, tłum. Monika Wyrwas-Wiśniewska, Zysk i S-ka, Poznań.

Sosnowska Anna, 1997, Tu, tam — pomieszanie, „Studia Socjologiczne”, nr 4.

Sosnowska Anna, 2008, Jakiego ustroju potrzebuja Polacy?, w: Jan Szomburg (red.), Modernizacja Polski. Kody kulturowe $i$ mity, Instytut Badań nad Gospodarką Rynkową, Gdańsk.

Staniszkis Jadwiga, 1991, Political Capitalism in Poland, „East European Politics and Societies", t. 5, s. 127-141.

Szelényi Iván, Treiman Donald J., Wnuk-Lipiński Edmund, 1995, Elity $w$ Polsce, $w$ Rosji i na Wegrzech. Wymiana czy reprodukcja?, Instytut Studiów Politycznych PAN, Warszawa.

Walicki Andrzej, 2004, Rosja Putina a polityka polska, „Przegląd”, 23 lutego. 
Wallerstein Immanuel, 1974, The Modern World-system, Academic Press, New York. Zarycki Tomasz, 2000, Politics in the Periphery: Political Cleavages in Poland Interpreted in Their Historical and International Context, „Europe-Asia Studies”, t. 52, s. 851-873. Zarycki Tomasz, 2003, Cultural Capital and the Political Role of the Intelligentsia in Poland, "Journal of Communist Studies and Transition Politics", t. 19, s. 91-108.

Zarycki Tomasz, 2004, Uses of Russia: The Role of Russia in the Modern Polish National Identity, „East European Politics and Societies”, t. 18, s. 595-627.

Zarycki Tomasz, 2007, The Values and Identification of the Younger Generation of the Russian and Polish Intelligentsia (Based on a Comparative Survey of College and University Students in Moscow and Warsaw), „Russian Education and Society”, t. 49, nr 11, s. 5-38.

Zarycki Tomasz, 2008, Kapitat kulturowy. Inteligencja w Polsce i Rosji, Wydawnictwa Uniwersytetu Warszawskiego, Warszawa.

Ziółkowski Marek, 1998, Miejsce spoteczeństwa polskiego w światowym systemie kapitalistycznym. Dylematy teoretyczne i praktyczne, „Kultura i Społeczeństwo”, nr 4.

\section{CRITICAL SOCIOLOGY IN THE PERIPHERIES}

\section{Summary}

The paper proposes a redefinition of the rules of critical sociology in the context of peripheral countries, among them Poland and also Russia and other countries of Central and Eastern Europe. The proposed theoretical model refers to the notions of cultural and political capital as understood and defined by Pierre Bourdieu. The cultural capital in particular is believed to be the key and most stable dimension of inequality in Poland, as well as an important source of inequalities in other dimensions. It has been suggested that critical sociology of the Polish periphery should focus its interests precisely on this issue. At the same time the position that overlooks the cultural dimension of inequalities and treats interests defined in terms of culture as "irrational" is considered to be a manifestation of "Orientalism" and lack of respect for the important social resources of the population.

\section{Key words/słowa kluczowe}

cultural capital / kapitał kulturowy; critical sociology /socjologia krytyczna; periphery / peryferie; symbolic domination / dominacja symboliczna 